\title{
The Use of Blended Learning Approach In EFL Education
}

\author{
Mohammad Naim Rahim
}

\begin{abstract}
The 21ST century education is a revolution that encounters the use of ICT (Information Communication Technology) as a component tool of education aligned with the contexts of teaching and learning. It is widely used in every surface of education particularly in teaching and learning EFL (English as a Foreign Language). When it comes to EFL education, traditional language teaching methodologies are intensively substituted with the new technological-integrated approaches. Currently, blended learning is used as an applicable approach and EFL education is surrounded by its features. It has really restructured the educational context and has paved the way for effective EFL practices. In fact, blended learning cooperates EFL educators a variety of interactive language activities while it is double component, integration of face-to-face education and technology-generated approaches. Therefore, this article investigates the use of blended learning approach in EFL education and undertakes an in-depth review of literatures, practices, and authentic enhancements of blended learning in the context of EFL education. The study enriches creative ideas toward the use of blended learning approaches in EFL classrooms. It indicates that blended learning approach provides a flexible language learning platform, endorse academic achievements of the learners, and influences EFL education.
\end{abstract}

Keywords: Technology, Blended Learning, Efl, Teaching Approach, Education

\section{INTRODUCTION}

Due to the new age revolution of ICT (Information Communication Technology) and its extensive integration into education, there has been research investigating the influence of technological tools and approaches in teaching and learning. Indeed, the use of technology in learning restructured education and paved the way for effective EFL practices. Today, technological-integrated approaches are a dependent indication of teaching and learning particularly in EFL education. In fact, it doesn't only facilitate as a learning tool but also it develops the policies for education and is widely used as a pedagogical factor in educational institutions.

In addition, there are many technological trends that became the core component of language teaching. ICT provides hundreds of online and offline tools for EFL practices. One can easily has accessed to applications and devices which are designed for education. This paradigm-shift in the surface of technology directly affects EFL education. Therefore, approaches for teaching and learning particularly language teaching are changed. Virtual education, distance learning, MOOCs, blended learning, and university learning platforms have been the main educational environments that have attracted the learners' interest.

Currently, blended learning is used as an applicable approach of education while it is a combination of traditional approaches of face-to-face education with technological-integrated approaches. According to Pappas (2018), aligned with the traditional language teaching and learning approaches, blended learning has been broadly applied as another module of education by schools and universities since the 1980s. Indeed, it is an integration of traditional face-to-face education and technological approaches which benefits both teachers and learners besides providing massive online educational resources.

According to Albiladi \& Alshareef (2019), blended learning is an upgraded educational approach that integrates traditional teaching methodologies with distance and online learning. In fact, blended learning is a revolution in teaching and learning EFL because of unfair use of traditional methodologies in the language teaching context before. In addition, student-centered learning is a matter for most of the institutions, but still it is not applied widely. So, aspects of using blended learning will also facilitate to student-centered learning as it is providing the learners with collaborative tasks and helps the teachers to design the learning activities more student-oriented.

In terms of EFL education, blended learning approach enhances anytime/anywhere learning while flexible learning platform is a demanding teaching and learning module in $21 \mathrm{st}$ century education. According to Ju \& Mei (2018), due to limited class hours, technological approaches facilitate life-long learning. Hence, blended learning approach provides this opportunity for EFL educators and encourages them to practice the language inside and outside the classroom. Indeed, blended learning can function as an essential method to learn a foreign language aligned with the current demands of education globally. It really supports the idea behind the literatures in this paper that blended learning approach provides the opportunity for language learners to use their brain effectively with ICT spaces to practice the language more authentically.

Reviewing the literatures, the study indicated that blended learning approach is a common suggestion for EFL classrooms. It is an applicable approach in the current educational setting. Zhang \& Zhu (2018) stated that by integrating features of technology and traditional learning, blended learning is an initial teaching and learning factor for 
higher education. Therefore, the current conceptual paper reviewed the recent related literatures on the use of blended leaning in the context of EFL education to provide a practical guideline of the related concepts which could enhance EFL practices. Based on the study investigations, the use of blended learning in the context of EFL education is thematised in the following core concepts.

\section{LITERATURE REVIEW}

\section{A. Blended Learning as a Combination of Traditional and Online Approaches}

In accordance with the emergence of technology and its integration into education, there have been several technological concepts used by educators. CALL (Computer Assisted Language Learning), MALL (Mobile Assisted Language Learning), and yet, many other online models are widely used in teaching and learning platforms. Blended learning is one of these technological-integrated approaches used in educational context which effectively incorporates to active language learning. According to Zhang \& Zhu (2018), it is difficult to develop an appropriate learning context for all of the learners, but the blended learning approach assists a flexible, interactive, encouraging, and inspiring teaching and learning environment. This really indicates the preference of blended learning module which is an integration of technological approaches and traditional methods of education.

Thus, blended learning incorporates as an applicable approach to replace the traditional methods with technological-integrated approaches of language teaching and learning. According to Dziuban et al. (2018), blended learning is a double component, integration of traditional face-to-face education with technological-generated platforms. Since the concept of blended learning is the integration of technology and online teaching and learning with traditional approaches, similarly the learners will have the interest to use both analog and digital spaces. In addition, Fakhir (2015) intended that MoEs (Ministry of Educations) should investigate more on the blended learning approaches. This indicates the need for exploring the use of blended learning approaches in education.

Indeed, blended learning integrates the existing teaching and learning practices to the new technological-oriented approaches. According to Albiladi \& Alshareef (2019), blended learning is accomplished as a creative idea for linking major fields like teaching approaches, educational technology, and online learning and teaching platforms. This signposts that the integration of technological trends with the traditional teaching and learning environments directed to the new phase in education which ultimately causes the restructuring of a new mind-set for the future of education, particularly in the EFL education.

\section{B. Blended Learning as a Flexible Language Learning Platform}

In fact, blended learning is an approach which motivates the learners to be responsible for their own learning strategies. According to Ghazizadeh \& Fatemipour (2017), blended learning provides a flexible learning platform for language

learners and the teachers. It supports the idea that blended learning is an approach which guides to anytime/anywhere education. Accordingly, Oweis (2018), investigated the effect of blended learning as impacting learners' achievement and motivation to learn English. This indicates that blended learning affects students' learning performance as well as motivates them to practice the language more authentically. Using blended learning, learners will have enough time and space to practice the language inside and outside the classrooms. This learning flexibility will provide the learners with a dynamic language input and promote their language proficiency.

Moreover, blended learning leads the institutions to have an upgrade EFL platform and restructure in-class teaching and learning spaces. According to Sharma \& Barrett (2018), a blended learning approach certainly has a place in the ELT (English Language Teaching) sector and, for certain institutions, blended learning platforms afford a range of fresh and innovative teaching opportunities. Therefore, the finding of this conceptual paper highlights the elements aligned with the previous studies that the use of blended learning versus the traditional approaches have resulted in many benefits not only for language learners but also in educational institutions arenas. For instance, integrating pedagogical objectives of the institutions, leading to self-directed learning, developing teaching and learning schemes for English language, enhancing learners' language skills, and improving the English language classrooms.

\section{C.Blended Learning and Learners' Academic Achievement}

Blended learning endorses the EFL learners learning performances. Akbarov, Gönen \& Aydoğan (2018) stated that EFL learners have the motivation to use blended learning while it enhances their professional performances. In fact, the motivation to use blended learning directly affects the learners' performance and this effective performance leads to the academic achievements. It also supports the idea that learners have a positive attitude towards the implementation of blended learning approaches in their classrooms. This issues the need for the use of blended learning in the EFL contexts. According to Ju \& Mei (2018), blended learning effects positively on learners' learning is being an effective approach which enhances the EFL learners' academic achievements.

Accordingly, using blended learning approach, learners evaluate their educational experiences (Dziuban \& Graham, et al, 2018). While EFL learners are able to evaluate their language learning process, it will ultimately enhance their academic achievement. Furthermore, blended learning preserves collaborative learning for students. The interactive outcomes express to decide on individual or active group learning environments. Whereas, Oweis (2018) declared that there is a significant difference on academic achievements as well as in terms of motivations between the learners treated traditionally and those language learners using blended learning modules. 
It evaluates the objectives for the current study that blended learning is an applicable approach for EFL education.

\section{D.The Influence of Blended Learning on EFL Education}

Since there is a need for restructuring the EFL education context where there are hundreds of technological trends integrating education. This enhancement can be possible by empowering the needs for doing further research on the use of blended learning approach in the EFL education. In addition, technological approaches specifically blended learning has evaluated educational demands. Dziuban et al (2018) stated that blended learning implications, outcomes and future directions are increasingly effecting educational settings. This indicates the need for paradigm-shifting in the language learning and teaching context and expresses a rapid influence of innovative approaches in the EFL education.

Currently, technology functions as a tool to enhance language proficiency. Language classrooms are equipped with major technological tools which influences the EFL practices effectively. According to Ja'ashan (2015), blended learning can be incorporated as a core approach to learn a foreign language with the existing trends of education. In addition, blended learning is not only facilitating the language learning process, but also it supports the EFL educators to accomplish multi pedagogical goals. Therefore, the study indicates that methodology shift in the EFL education is an issue where technological innovative approaches are the key to address this gap.

However, Shebansky (2018) claimed that transaction from traditional teaching methodologies to the technological educational schemas is the nature for a better education. It highlights the need for restructuring the language teaching schemas and providing the learning platforms with these technological trends to influence the educational sitting pedagogically. This indicates that paradigm-shifting in terms of integrating technological approaches will also influence the EFL education. It also provides the EFL learners with a variety of collaborative tasks. In addition, using blended learning incorporates EFL educators with contextualized content of language delivery.

Obviously, blended learning platforms help EFL learners to enhance the language skills, motivates them to be more independent learners, and influences their language proficiency. Albiladi \& Alshareef (2019) signposted that blended learning enhances the language skills development, boosts the English language learning contexts, and encourages learners to learn the language authentically. This is aligned with the objectives in this conceptual paper that the use of blended learning approaches develops critical-thinking skills of the EFL learners, promote learning and teaching quality, and utilize a generative learning environment.

\section{E. Barriers and Opportunities of Using Blended Learning} in EFL Education

There are some issues on how to apply blended learning approach in the EFL classrooms. However, majority of recent studies claimed that there is common perception by both language teachers and the EFL learners that blended learning approach has the efficiency to develop the educational arenas.

Zhang \& Zhu (2018) highlighted that applying blended learning approach effected learners' academic achievements in the EFL education in comparison to learners who had attended traditional face-to-face classrooms.

In fact, adoption of blended learning approach needs time and commitment to replace the traditional methods of education with these technological-integrated approaches. In addition, paradigm shift in educational setting from traditional to integration of blended learning approach and merging it with the EFL context requires further research. Since it is the combination of traditional methods and online learning approaches, investigations should be done on major implementation of them when they come to EFL education.

Reviewing the available literatures, elements that influence adoption of the blended learning approach in the EFL education are stated as lack of technical support, ICT knowledge of the instructors and curricula alignment with technology. Since, there were some common themes in terms of obstacles for the use of blended learning approach in the EFL education, this study examines the investigation done by Riel, Lawless \& Brown (2016). It evaluated six elements that the teachers encounter while applying blended learning approach.

Thus, the first barrier is investigated as lack of learners' cooperation to complete a task based on curriculum using blended learning approach. In fact, learners face peers' miscommunication to complete a task. Second, using blended learning approach, learners face mismanaged while it is also a challenge for the educators to keep the learners concentrated on the given task. Third, task assignment among learners. Applying blended learning, it is difficult to assign the roles among learners to participate in a particular activity. All these three barriers come with the criteria involving learners.

In addition, there are three more barriers encountering educators. First, blended learning approach and curriculum alignment. Using blended learning is time-consuming for educators specifically when they need to apply all teaching activities according to pre-determined curricula by the institution. Secondly, since blended learning also provides the opportunity for out-class learning, it is still a barrier for educators to control the learners' participation in out-class activities. Sixth, lack of ICT knowledge of the teachers is another barrier for the use of blended learning. These are some of the barriers which may affect successful implementation of blended learning approach in EFL education.

In brief, there is less literature on functional effectiveness of blended learning approaches rather than explaining on how to implement it. Tomlinson \& Whittaker (2013) revealed that there are two reasons for using blended learning approaches, improving language learning effectiveness and cost control. The finding in this study also states that there is a commitment on using blended learning in EFL education since it is costs saving and is associated with technological innovations in education. Based on the literatures of the study, technology 
particularly blended learning facilitates to achieve learning outcomes more authentically in EFL education. However, the term cost saving is eventually a highlighted factor investigated through reviewing the literatures in this paper where it is aligned with the objectives to investigate on the use of blended learning in EFL education.

\section{CONCLUSION}

The study concludes that blended learning approach is an integration of online education with traditional methods which can be applied effectively for EFL education enhancements. It provides a flexible learning platform, endorses EFL learners' motivation toward authentic language learning practices, and leads to better academic achievement. In addition, there is a significant difference in terms of language proficiency and motivation between EFL learners dealing with blended learning approaches and learners treated by traditional face-to-face classrooms.

As well as, the study highlighted practical improvement that blended learning approach enhances the EFL learners with collaborative language activities and facilitates them with interactive language skills. The investigation also indicated EFL learners and teachers' perceptions toward the use of blended learning approach and extended a positive attitude for its successful implementation. However, studies intended some barriers for the use of blended learning approach in the EFL education which needs to be addressed through further investigations.

\section{ACKNOWLEDGMENT}

I appreciate the contributions, try-less efforts, and instructions of LCPIS 2019 (2nd Language and Communication Postgraduate International Seminar). They put a great impact on organizing and completing this research. They really know about greatness in language teaching which extremely improved my article.

\section{REFERENCES}

1. Albiladi, W. S., \& Alshareef, K. K. (2019). Blended learning in English teaching and learning: A review of the current literature. Journal of Language Teaching and Research, 10(2), 232. DOI:10.17507/j1tr.1002.03.

2. Azamat Akbarov, A.; Gönen, K.; \& Aydoğan, H. (2018). Students' attitudes toward blended learning in EFL context. Acta Didactica Napocensia, 11(1), 61-68. DOI: 10.24193/adn.11.1.5.

3. Dziuban, C., Graham, C. R., Moskal, P. D., Norberg, A., \& Sicilia, N. (2018). Blended learning: The new normal and emerging technologies. International Journal of Educational Technology in Higher Education, 15(1), DOI:10.1186/s41239-017-0087-5.

4. Fakhir, Z. (2015). The impact of blended learning on the achievement of the english language students and their attitudes towards it (Master's thesis). Middle East University. Retrieved from https: //meu. edu. jo/library Theses/ 5874904ebbd3b_1.pdf.

5. Ghazizadeh, T., \& Fatemipour, H. (2017). The effect of blended learning on efl learners' reading proficiency. Journal of Language Teaching and Research, 8(3), 606-614. DOI:10.17507/jltr.0803.21.

6. Ja'Ashan, M. M. (2015). Perceptions and attitudes towards blended learning for english courses: A case study of students at University of Bisha. English Language Teaching, 8(9), DOI:10.5539/elt.v8n9p40.

7. Ju, S. Y., \& Mei, S. Y. (2018). Perceptions and practices of blended learning in foreign language teaching at USIM. European Journal of Social Sciences Education and Research, 12(1), 170. DOI:10.26417/ejser. v12i1. p170-176.

8. Oweis, T. I. (2018). Effects of using a blended learning method on students' achievement and motivation to learn English in Jordan: A Pilot Case Study. Education Research International, 2018, 1-7. DOI:10.1155/2018/7425924.

9. Pappas, C. (2018, March 22). The history of blended learning. Retrieved from https://elearningindustry.com/history-of-blended-learni ng.

10. Riel, J., Lawless, K. A., \& Brown, S. W. (2016). Listening to the teachers: Using weekly online teacher logs for ROPD to identify teachers' persistent challenges when implementing a blended learning curriculum. Journal of Online Learning Research, 2(2), 169-200.

11. Sharma, P., \& Barrett, B. (2018). Best practices for blended learning. Hove East Sussex: Pavilion Publishing and Media.

12. Shebansky, W. J. (2018). Blended learning adoption in an ESL context: Obstacles and guidelines. TESL Canada Journal, 35(1), 52-77. DOI:10.18806/tesl. v35i1.1284.

13. Tomlinson, B., \& Whittaker, C. (2013). Blended learning in English language teaching: Course design and implementation. London: British Council.

14. Zhang, W., \& Zhu, C. (2018). Comparing learning outcomes of blended learning and traditional face-to-face learning of university students in ESL courses. International Journal on E-Learning, 17(2), 251-273

\section{Authors ProfiLe}

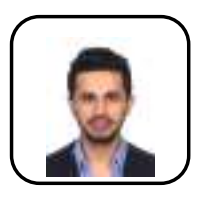

Mohammad Naim Rahim is a postgraduate student M.Ed. TESL (Master of Education in Teaching English as a Second Language) at University Technology Malaysia $\mathrm{He}$ is also a Teaching Assistant in English Language \& Literature Department at Kunduz University, Afghanistan. He is a poet and has published his first poem book in 2017. Currently, he is doing his thesis on e-learning and EFL educations. His research focus is second language acquisition and technology. The current paper is the third piece of his research publications on technology and teaching/learning English language. 